\title{
Framing the flood: a media analysis of themes of resilience in the 2011 Brisbane flood
}

\author{
Erin L. Bohensky • Anne M. Leitch
}

Received: 10 January 2013/ Accepted: 25 February 2013/Published online: 28 March 2013

(C) The Author(s) 2013. This article is published with open access at Springerlink.com

\begin{abstract}
In the wake of the flood that affected Brisbane, Australia, in January 2011, public attention turned to the causes of the event and lessons for minimizing the impacts of future floods. The news media was an important vehicle for understanding and internalizing the 2011 Brisbane flood. Examining how the flood was framed in the media is, therefore, useful to understand broad public perception of floods. We undertook a systematic newspaper analysis during a one-year period to explore media framings of the flood, focused on learning as an aspect of resilience in relation to two themes: (1) perceived links between the flood and climate change and (2) perceived roles of government in managing the flood. We show that media coverage of the flood reinforces aspects of resilience by acknowledging community spirit, self-reliance and the importance of sharing experiences for learning; articulating the risk of extreme events in a changing climate; and highlighting regional management trade-offs. Much of the discourse is likely to inhibit resilience, however, by casting the flood in terms of blame and political opportunity and paying inadequate attention to longer-term aspects of regional resilience. The limited learning observed to date may highlight a need for other mechanisms and actors to
\end{abstract}

E. L. Bohensky ( $\square)$

CSIRO Ecosystem Sciences and Climate Adaptation Flagship, ATSIP, James Cook University, Townsville, QLD 4811, Australia

e-mail: erin.bohensky@csiro.au

\section{A. M. Leitch \\ CSIRO Climate Adaptation Flagship, Brisbane, \\ QLD 4001, Australia}

\author{
A. M. Leitch \\ ARC CoE Coral Reef Studies, James Cook University, \\ Townsville, QLD 4811, Australia
}

lead learning processes. As policy related to the 2011 Brisbane flood, and extreme events more generally, is influenced by the public discourse, it is important to understand the nuances of communication around these events and the media's role in reinforcing or changing perceptions.

Keywords Climate change - Community - Discourse . Government $\cdot$ Learning $\cdot$ Natural disaster

"... the floods of this year will help define the character of 21 st century Brisbane. Out of the adversity, we have the ability to define that character as positive and resilient" (Journalist, The Courier Mail, 12 January 2011).

"The urgency of the flooding has created natural, almost adrenalin-driven responses, but the recovery will require a great deal of patience, stamina and capable administration" (Journalist, The Courier Mail, 15 January 2011).

\section{Introduction}

In January 2011 the region of South East Queensland (SEQ), which includes the state capital city of Brisbane, experienced one of its largest floods in a century, making international headlines as extreme rainfall events around the world raised the spectre of climate change (Min et al. 2011; Coumou and Rahmstorf 2012). Known as the "2011 Brisbane flood", the event was Australia's most expensive natural disaster in history (van den Honert and McAneney 2011; QFCI 2012). The Queensland Government launched an inquiry into the 
causes of and responses to the Brisbane flood and other flood events across the state (QFCI 2012) and resulted in Australia's largest class action to date. For a region such as SEQ, resilience to a changing climate is evident in the ability to cope with, plan for and learn from natural disasters (Adger et al. 2005; Smit and Wandel 2006). This ability depends to some degree on a region's "inherent resilience" (Colten et al. 2012) which involves the practices retained in its collective social memory that it deploys to respond to disruption, and how this affects the ability to learn, and subsequently adjust, individual and institutional behaviour in the future (Adger 2000; Godschalk 2003; Turner et al. 2003; Colten and Giancarlo 2011).

Parallel to the formal inquiry process, another mechanism plays a key role in shaping societal learning in SEQ about the Brisbane floods and resilience to future floods more generally: the Australian news media. News media both reflects and shapes public opinion by defining and limiting public discourse around key events (Holliman 2004; Miles and Morse 2007) and contributes to the sense making and informal learning of the community (Nisbet and Feldman 2011). Of particular relevance to flood events is that the media is a powerful force for influencing public perceptions of risk (Carvalho and Burgess 2005) and plays a role at both the affected and broader scale in psychological and physical coping or recovery processes (Gortner and Pennebaker 2003).

During and after the 2011 Brisbane flood, the news media was one important vehicle of several through which the flood could be understood and internalized. Examining how the flood was framed in the media provides insight into the broad public perception of floods. In particular, analysis of local and national newspaper reporting of the Brisbane flood illuminates how experience of a natural disaster frames perceptions of climate change and perceptions of governments' ability to respond to a disaster event. In this paper, we argue that the framing of the 2011 Brisbane flood in Australian newspaper reporting is likely to be an important influence on individual, community and regional adaptability to future extreme events. We present an analysis of the concept of learning as an aspect of resilience to natural disasters, focusing on two themes: (1) perceived links between the flood and climate change and (2) perceived roles of government in mitigating and responding to the flood. We discuss the implications of this analysis for informing and applying resilience theory, for improving Brisbane's resilience to floods, and for adapting to climate change.

\section{Analytical framework}

Resilience is gaining momentum as a concept that underpins natural disaster and climate adaptation policy in
Australia (Commonwealth of Australia 2011; EMQ 2011). Still, there has been little critical inquiry into what resilience means in this context and little guidance for individuals, communities and governments regarding behavioral or procedural change that they should adopt as a consequence. For example, one view gaining currency suggests that resilience can be defined and measured by focusing on three attributes (Walker et al. 2002): maintenance of structure and function in the face of disturbance, ability to self-organize in response or anticipation to disturbance and capacity for learning and adaptation. While empirically supported to some extent through a range of social-ecological system case studies (Anderies et al. 2006), these theoretical characteristics of resilience beg for some refinement when applied to a disaster context (Manyena 2006; Whittle et al. 2010; Brown and Westaway 2011; Walker and Westley 2011). Examination of resilience discourses in other contexts suggests inconsistency and even confusion in the application and fundamental purpose of adopting a resilience framework (Brown 2011).

In this paper, we focus primarily on learning, an important aspect of building resilience to recurring events such as floods (Whittle et al. 2010). We consider community resilience to disasters as the "ability to learn from extreme events and institute individual and institutional adjustments" (Colten and Sumpter 2009). Communities can be described as resilient to such disturbances if they exhibit "a process linking a set of adaptive capacities to a positive trajectory of functioning and adaptation after a disturbance" (Norris et al. 2008, p. 130). Following a catastrophe, memory becomes the "growth points for renewal and reorganization of the social ecological system" (Adger et al. 2005, p. 1037; also Folke et al. 2005). Colten and Sumpter (2009) stress the importance of a specific theoretical and practical focus on social memory to foster resilience.

We look firstly at the media discourse regarding the relationship between the Brisbane flood and climate change. Despite a general scientific consensus that anthropogenic climate change is among the most pressing challenges for humanity (Hansen et al. 2008; Rockström et al. 2009) and is likely to intensify extreme events (IPCC 2007), there is limited understanding of the factors that motivate individuals to alter their perceptions and behavior about climate adaptation in anticipation of, or following, an extreme event. Spence et al. (2011) found that flood victims in the UK were more likely than others to express concern about climate change. Whitmarsh (2008), however, found only a tenuous link between direct flood experience and risk perception and behavioral change and inferred that people in their study did not attribute the floods they experienced to climate change. However, the role of perceived causation of floods and other extremes of 
climate has yet to be thoroughly scrutinized in the international literature, and the significance of "indirect" experience of extreme events has not received much attention in understanding motivations for behavioral change related to climate adaptation. Additionally, views on climate change and its risks are socially constructed (Sonnett 2010). In this analysis, we therefore focus on regional community perceptions of climate change as expressed through the media discourse in relation to the flood event.

Secondly, we examine perceptions in the media discourse of government response to the flood. As extreme events become more frequent or larger in magnitude, and federal government resources for emergency response are increasingly under strain, local and regional governments are confronted with community expectations for preventing, preparing for, responding to and recovering from extreme events. Disasters tend to expose government responses as well as reset a region's social, economic and political regional forces (Liu et al. 2008). They can provide windows of opportunity for learning as governments can support resilience through "retooling policies" that help communities to become less vulnerable in the future and to build opportunities not just to return to normal but to improve standards and retain assets and correct flaws or social inequities while rebuilding (Liu et al. 2008). However, disasters can also inhibit resilience as governments reinforce vulnerabilities when they face difficult trade-offs or act hastily to restore normalcy to a disaster-affected region (Pelling 2003).

\section{Case study}

\section{The South East Queensland context}

The floods in SEQ in 2011 resulted from the convergence of historical and seasonal factors. SEQ is a rapidly urbanizing region with a current population estimated to be 3.2 million and expected to grow to 4.2-5.1 million people by 2031 (Roiko et al. 2012). Established on a floodplain in the 1880s, the city of Brisbane has experienced several major floods including events in 1841, 1893 and 1974 (BoM 2011). The "74 flood" was a defining event for the people of Brisbane. Peaking at $5.45 \mathrm{~m}$ and with insured losses of about $\$ 2.3$ billion (van den Honert and McAneney 2011), the 74 flood prompted changes in the Brisbane River catchment, significantly the construction of the Wivenhoe Dam in 1984. With the dual role of water security and flood mitigation, the construction of the Wivenhoe Dam led to the popular belief that Brisbane was "flood proofed" (Pittock 2011). The decade-long drought in the SEQ region in the early 2000s, which almost emptied
Wivenhoe Dam but led to development of the SEQ “water grid" to improve regional water distribution, shifted the focus of water resource management from flood mitigation to water security (Hayes and Goonetilleke 2012). Additionally, in the decades following 1974, the urban footprint of Brisbane changed due to increasing wealth, rapid population growth and urban development, resulting in significant development of waterways and the SEQ floodplain.

Summer 2011: a record-breaking wet season

In Queensland 2010, the wettest spring on record was followed by a record-breaking wet December due to the strongest La Niña effects since 1917 and a strong monsoon (BoM 2011; Nicholls 2011). Continuing heavy rain through January 2011 led to almost three-quarters of Queensland being declared a disaster zone. From 9 to 13 January, direct rainfall of $480 \mathrm{~mm}$ fell into Wivenhoe Dam, exceeding its capacity. The massive inflows and the need to protect the integrity of Wivenhoe Dam led to SEQ Water (the agency responsible for managing SEQ's government-owned dams) allowing controlled releases of water to prevent the dam wall failing. Contentiously, these controlled releases were alleged, at the time, to have followed the dam operational manual and state flood management policies, but contributed to flood levels below the dam.

The extreme weather conditions in late 2010 through January 2011 led to two linked major flood events in SEQ. The first was a flash flood, described by Queensland Premier Anna Bligh as an "inland tsunami", that occurred on 10 January in the inland city of Toowoomba and then further downstream in the rural Lockyer Valley: 25 people lost their lives. The second flood was of downstream cities of Ipswich and Brisbane. On 12 January, the city flood gauge exceeded its major flood level $(4.30 \mathrm{~m})$ in Brisbane and central power was switched off through the central business district. On 13 January, the flood peaked at $4.46 \mathrm{~m}$ (a new record since 1974), affecting 14,100 properties including the inundation of 1,203 houses and 2,436 businesses (QFCI 2011). Public and private river infrastructure was washed downstream including pontoons, jetties, a floating restaurant and several hundred metres of floating public boardwalk. By 14 January, the water level fell below its minor flood level; by 15 January 5,930 properties were still affected with 175 still completely inundated (QFCI 2011).

Following the flood, there was an overwhelming community response of clean-up volunteers, dubbed the "Mud Army". The Mud Army comprised 62,000 registered (and an estimated 180,000 unregistered) volunteers-many of whom reported they were motivated by media images of flood damage - to help clean up Brisbane's streets and 
Table 1 Summary of articles analyzed

\begin{tabular}{|c|c|c|c|c|c|c|c|c|c|}
\hline \multirow[t]{2}{*}{ Search terms } & \multirow{2}{*}{$\begin{array}{l}\text { Number of } \\
\text { articles } \\
\text { analyzed }\end{array}$} & \multicolumn{2}{|c|}{ Time period } & \multicolumn{3}{|c|}{ Geographic scale } & \multicolumn{2}{|l|}{ Type } & \multirow{2}{*}{$\begin{array}{l}\text { Articles by } \\
\text { community } \\
(\%)\end{array}$} \\
\hline & & 2011 & 2012 & $\begin{array}{l}\text { National } \\
\text { newspapers }\end{array}$ & $\begin{array}{l}\text { Brisbane } \\
\text { newspapers }\end{array}$ & $\begin{array}{l}\text { QLD } \\
\text { regional } \\
\text { newspapers }^{\mathrm{a}}\end{array}$ & Journalist & $\mathrm{LTE}^{\mathrm{b}}$ & \\
\hline $\begin{array}{l}\text { Flood } *+\text { Brisbane }+ \text { "climate } \\
\text { change" or "global warming" }\end{array}$ & 109 & 101 & 8 & 34 & 48 & 27 & 65 & 44 & 40 \\
\hline Flood $*+$ Brisbane + government & 405 & 287 & 118 & 178 & 177 & 50 & 191 & 214 & 53 \\
\hline
\end{tabular}

a Includes regional cities or areas of QLD (i.e. Cairns, Gold Coast, Townsville)

b Letters to the Editor. Also includes Chatroom, Text the editor, etc.

homes (McDonald et al. 2012). Immediately after the floods, the (already poorly polling) Labor government led by Bligh set up an inquiry, the Queensland Floods Commission, to investigate: preparation and planning for the floods and adequacy of the response; management of essential services; the adequacy of forecasts and warning systems; performance of insurers; the operation of dams; and land use planning (QFCI 2011). The inquiry released its final report the following year on 16 March 2012: just eight days before the Queensland State Government election on 24 March 2012 and five weeks before the local government polls on 28 April 2012.

\section{Methods}

Newspapers, even in times of declining readership and increasing electronic news dissemination, still play a key role in opinion formation of decision-makers (Miles and Morse 2007; Nisbet and Feldman 2011). As a source of social data, newspaper articles have a number of advantages. They provide data that are easily accessible and have high spatial and temporal resolution, through a method that is non-intrusive, allowing a sensitive, ethical approach to eliciting perceptual data from disaster-affected communities at a time when other methods may be untenable. They incorporate a breadth of views as they are written by a range of actors, generally journalists who, in turn, also draw on multiple actors as sources of information (Carvalho 2008). However, like other types of social data, use of news media also includes assumptions and caveats that require a cognizance of the filtering and framing that occurs through journalistic practices (Boykoff 2011).

In this study, we used a combined deductive and inductive approach drawing on the analytical framework described by Doulton and Brown (2009); key terms guided our selection of articles but narratives-observations woven together to construct meanings (McComas and Shanahan 1999) — were identified inductively (Bohensky and Leitch 2012). We searched an online newspaper archive,
NewsBank (www.newsbanklibraries.com), for articles published in print editions. A methodological challenge with media analysis is how to define and limit the sample (Carvalho 2008); we thus selected media articles collected from two time periods regarded as critical discourse periods: (1) during the Brisbane flood event and (2) the one-year anniversary coverage of the flood (which also just preceded the delivery of the Commission's final report leading up to the March 2012 state election). We searched all national and Queensland newspapers, a total of 47 publications. Articles included those written by journalists as well as opinion columns and community responses. The community responses included letters to the editor (LTE) and similar, but generally shorter, published responses variously titled "Talking Point", "Chatroom", "Text the editor", "Last Post" or "Your Say". Because both content types contribute to the collective discourse and were largely similar in their views, they were not treated as distinct data sets in this analysis. The set of articles was imported into the qualitative software program NVivo 10 (QSR) and filtered to remove articles that reported mainly on issues beyond the spatial or temporal scale of our study (e.g. excluding articles about flood events elsewhere in Queensland, or mainly about Cyclone Yasi in north Queensland on 3 February 2012).

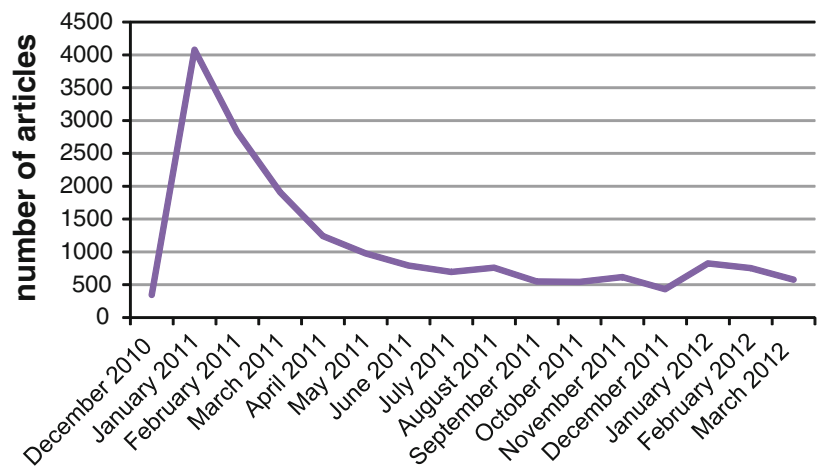

Fig. 1 Temporal distribution of articles containing the words "Brisbane" + "flood*" in Australian national and Queensland newspapers during December 2010 to March 2012 
To indicate the extent of media coverage of the flood, nearly 12,000 articles containing "flood*" and "Brisbane" were published in these newspapers during the six-month period following the floods. The vast majority of these covered the event itself and its impacts, typical of reporting on disasters. More specific searches using key words "climate change" and "global warming" and "government*" reduced this number significantly. To ensure a manageable sample size for qualitative analysis, we collected articles from the beginning of the flood event for six months on the climate change query (resulting in 101 articles for analysis) and for two months on the government query (resulting in 287 articles for analysis). We also collected articles from the beginning of the one-year anniversary of the flood event for three months, returning eight articles for analysis for the climate change query and 118 articles for the government query (Table 1). For all searches, the majority of articles collected were for the period around the event, with a major peak in January 2011 and a secondary peak in January 2012 (Fig. 1). Coding of articles was done by two researchers as an iterative process involving reading through the data at least three times. One researcher took responsibility for the climate change query and the other for government, and results were discussed among the researchers and revisited to verify the validity and consistency of coding.

\section{Results}

Discourse on climate change

We investigated the climate change discourse for evidence that the flood event was a catalyst for learning about a changing climate. In this analysis, we were interested in the main narratives about the relationship between the Brisbane flood and climate change. We identified these in the media sample as: (1) belief that a link can be made between floods in general and climate change, (2) denial of a relationship between the flood and climate change, (3) confusion about the relationship and (4) belief that the 2011 Brisbane flood is proof of climate change (Table 2). Below we describe the main lines of argument of each narrative and present sample quotes. Additional quotes are given in Table 3. In identifying narratives, we considered the context of the relevant statements and the overall tone of the article. Multiple narratives could be identified in a small number of articles.

\section{Linking climate change: "compelling evidence"}

A dominant narrative indicates that the floods stimulated people to link, or at least explore the possibility, that natural disasters such as floods signal a changing climate (43 articles). This narrative argues that a link can be made between climate change and floods in general, largely on the basis that extreme events are becoming more frequent: "No one is denying there has been flooding and other natural disasters before but if climate change isn't happening then why has the frequency of these incidents increased? Do some research and check out the non-government funded scientific evidence. Pull your heads out of the sand and stop making uninformed ignorant comments" (Chatroom, The Gold Coast Bulletin, 17 January 2011). This view acknowledges that climate change science relies on evidence based on trends, not single events: "multiple once-in-100-years events back-to-back is compelling evidence that something is changing" (LTE, The Australian, 3 February 2011).

Some articles note that despite scientific consensus, the science of climate change has uncertainties associated with it and in this light advocate the precautionary principle. This narrative also reflects pragmatic concerns and implications, such as how to proactively and comprehensively "climate-proof" through improved design for flood insurance.

\section{Denying climate change: "surrendering responsibility"}

Roughly equal in its dominance was the Denying narrative (44 articles), which argued that to link the flood event and

Table 2 Number, time period, geographic scale and type of articles containing climate change narratives

\begin{tabular}{|c|c|c|c|c|c|c|c|c|c|}
\hline \multirow[t]{2}{*}{ Narrative } & \multirow[t]{2}{*}{ Number of articles } & \multicolumn{2}{|c|}{ Time period } & \multicolumn{3}{|c|}{ Geographic scale } & \multicolumn{2}{|l|}{ Type } & \multirow{2}{*}{$\begin{array}{l}\% \text { of articles that } \\
\text { are LTE }\end{array}$} \\
\hline & & 2011 & 2012 & National & Brisbane & Regional $^{\mathrm{a}}$ & Journalist & $\mathrm{LTE}^{\mathrm{b}}$ & \\
\hline Linking & 43 & 40 & 3 & 7 & 33 & 3 & 35 & 8 & 19 \\
\hline Denying & 44 & 41 & 3 & 15 & 8 & 21 & 13 & 31 & 70 \\
\hline Confusing & 15 & 13 & 2 & 10 & 3 & 2 & 11 & 4 & 27 \\
\hline Proving & 7 & 7 & 0 & 2 & 4 & 1 & 6 & 1 & 14 \\
\hline Total & 109 & 101 & 8 & 34 & 48 & 27 & 65 & 44 & 40 \\
\hline
\end{tabular}

\footnotetext{
${ }^{a}$ Includes regional cities or areas of QLD (i.e. Cairns, Gold Coast, Townsville)

${ }^{\mathrm{b}}$ Letters to the Editor. Also includes Chatroom, Text the editor, etc.
} 
Table 3 Narratives and sample text concerning relationship between Brisbane flood and climate change

Sample text

Linking climate change (43 articles)

Insurance implications

Denying climate change (44 articles)

Floods used to support climate policy

Floods used to support climate policy

Pointing to drought as evidence against climate change, and to experts "getting it wrong"

Past flood record as evidence against climate change

Past flood record as evidence against climate change; influence of political parties

Escaping responsibility; idea that "nature" but not "climate change" caused floods (but also developers and councils)

Treating "mother nature" and climate change as mutually exclusive

Confusing climate change (17 articles)

Confusion about sea-level rise/floods
"Insurers are now worried they may not be able to map or price the risk of flooding in order to set a premium", the climate change report noted. If insurance companies of the future are reluctant to cover flood and fire, they will be even more reluctant to cover homes and businesses for the risks of storm surge, landslip and sea-level rise. The report added:

"Risks from climate change will build on and compound these areas of existing risk and uncertainty" (Houghton, Courier Mail, 15 January 2011)

My question is did Bligh govt purposely open the dams to flood qld to put climate change fear into ppl to reinforce their agenda on carbon tax? (Chatroom, The Gold Coast Bulletin, 14 June 2011)

The black-coal capital of Australia is overwhelmingly against the Gillard Government's carbon tax and has dismissed suggestions the recent spate of natural disasters were because of man-made climate change (Viellaris, The Sunday Mail, 5 June 2011)

In 2007, the Australian of the Year famously argued that in Adelaide, Sydney and Brisbane, water supplies were so low they urgently needed desalination plants, possibly within 18 months. Australians, he said, needed to stop worrying about drought and start talking about the "new climate". Somehow, we don't think he had this year's floods in mind (The Australian, 11 February 2011)

Coalition regional development spokesman Barnaby Joyce said it was absurd for Senator Brown to blame the coal industry for floods, which had been a reality in Queensland throughout its history. "In 1893, the flood gauge on the Brisbane River reached $8.35 \mathrm{~m}$, so was the coal industry responsible for that as well?" he asked (Uren, The Australian, 17 January 2011)

Between 1840 (when the first records were taken) and 1901 there was, on average, one flood as big as 1974 every 15 years. In the twentieth century the climate changed (as it always does) and we have had two big floods in 110 years. There were a lot more floods in the 19th century and I don't think they had much in the way of global warming or rising $\mathrm{CO}_{2}$ levels back then

It is sad to think that our current federal government has an alliance with the Greens and that every decision Julia Gillard makes has to be approved by Bob Brown (Chapel Hill, Qld, LTE, Australian, 18 January 2011)

There is no need for Anna Bligh to throw money away on an inquiry to find out who or what was to blame for the floods, when that money could be used to help those affected. Blind Freddy could tell her the causes: nature, greed, ineptitude and stupidity. Nature is selfexplanatory; greed of developers for building inappropriate houses in flood-prone areas; and greed, ineptitude and stupidity of councils which allowed this. Nature, despite the ravings of the climate-change boffins, we cannot control (Malanda, LTE, Sunday Mail, 23 January 2011)

If Senator Brown needs to blame someone or something, maybe he should target good old mother nature (Outer Sydney, LTE, Courier Mail, 17 January 2011)

Hey just a thought for all you greenies/climate change people if melting polar ice caps will raise the sea levels what happens when all the flood water goes out to sea? - confused (Chatroom, The Gold Coast Bulletin, 20 January 2011) 
Table 3 continued

\section{Sample text}

Confusion caused by muddling the different consequences of climate change and their causes

Promotion of "balance as bias" phenomena in reporting; treating La Nina and global warming as mutually exclusive causes of natural disasters

Not enough evidence

Emphasis on contradiction, polarization

Highlighting "no evidence"; lack of clarity regarding impact of La Niña

Climate-change impacts are restricted to coastal storms (also "Denying Climate Change")

Proving climate change (7 articles)

Reference to expert statement; cost of climate change and adaptation
Queenslanders had a glimpse of the future this week when 23 towns and cities were swallowed by floodwaters. The water will recede and a costly clean-up will begin. But brace yourself: it could start all over again with devastating effect, perhaps in coastal areas not yet hit. But in the not-too-distant future, in low-lying coastal zones including the Gold Coast, Cairns, Hervey Bay and Moreton Bay, the waters will not recede. And the inundation won't be rainwater, but sea water.

Professor John Cole, the director of the University of Southern Queensland's Centre for Sustainable Business and Development, says climate change and rising sea levels during the next century will mean so-called one-in-100-year severe weather events will happen far more frequently (Houghton, Courier Mail, 8 January 2011)

Scientific opinion continues to be divided over how much the flooding and cyclones-Yasi followed hard on the heels of category 3 Cyclone Anthony that hit Bowen, between Townsville and Mackay, on January 30 - owe to the La Nina effect or to the wider impact of global warming (Walker, Bita, Owens, Weekend Australian, 12 February 2011)

We certainly can't say there is or isn't a global warming signal because the work's not been done (Thomas, Greer and Anderson, The Australian, 19 January 2011)

"What happens in Queensland or what happens in Russia or for that matter the floods in the Mississippi River right now, whether there is a link between those and climate change is very difficult to establish. So I don't think anyone can make a categorical statement on that." [IPCC Chairman Dr Rajendra Pachauri said]

Dr Pachauri's comments contradict assertions by Greens leader Bob Brown in the wake of the floods that the coal industry was to blame because the sector's contribution to global warming was responsible for the extreme weather conditions

Scientists had concluded that the floods were caused by record high temperatures in the oceans around Australia, Senator Brown said at the time (Lloyd, The Australian, 17 May 2011)

Australia did its best for global cooling in 2011 but it had nothing to do with the federal government's carbon tax

And for those looking to the figures to disprove climate change, the Bureau of Meteorology says Australia was the only continent to record cooling and the nation's 10-year temperature average trend was still up

Mr Jones said there was no evidence to link the strong La Nina weather systems with changing global temperatures (Lloyd, The Australian, 5 January 2012)

Questions must also be asked about Queensland's climate-change plan, which warns of a threat to Brisbane from cyclones, storm surges and seas rising in the east. This week's disaster came from the west. When warm ocean air is pushed inland to the Great Divide, it rains. When this occurs in extraordinary amounts, some of the water rolls west, spreading across the slopes and plains and threatening country towns. But the deluge can also roar down the range, rushing to the coast below. There is nothing we can do to stop this enormous, natural recycling system (Weekend Australian, 15 January 2011)

Prof Garnaut said Australia was already paying a high price to adapt to climate change - through desalination plants and the big clean-up bills for extreme weather such as this year's floods and cyclones. This made it more prudent to invest in mitigation (Atkins, The Courier Mail, 4 February 2011) 
climate change was to excuse other causal factors of the flood: "To stand back helplessly and blame the summer's tragedies on climate change is to surrender responsibility for those things that we can control" (Journalist, Weekend Australian, 12 February 2011). The flood was also blamed on "nature" or downplayed compared to the previous floods. Climate change is used to explain both drought and flood: this is seen as the "experts getting it wrong" when they raised alarm about droughts only a few years earlier. Similarly, climate change "advocates" are attributing all natural disasters to climate change, despite the existence of these events in the pre-industrial record: this defers responsibility for other causes of the flood. Climate change is used by politicians to push through unpopular policies: "carbon dioxide in the atmosphere had nothing to do with the recent severe flooding in Australia. Making exaggerated claims regarding $\mathrm{CO}_{2}$ only shows what length some people will go to in order to score political points for the introduction of a big new (carbon) tax on everything" (LTE, The Australian, 20 January 2011). Notably, this narrative refers to the historical past and the idea that the present can be understood as a continuation of this past. The tenor of this narrative is often highly emotive, using words such as "villain", "fear" and "cataclysmic".

Community responses comprised 70 per cent of articles expressing the Denying narrative, a higher percentage than in other narratives. This narrative contains various, and at times, conflicting notions of who or what is to blame for the Brisbane flood; for example, one reader points to "nature, greed, ineptitude and stupidity" as the causes of the flood, suggesting that "nature, despite the ravings of the climate-change boffins, we cannot control". Some articles suggested that making a link between floods and climate change is injurious to the Australian spirit of helping one another, and disrespectful of local agency by accepting fate and the uncontrollability of nature. One editorial quipped "To argue we are powerless before storm and floods is to admit defeat, and that is not the Australian way. And definitely not the Queensland way" (Weekend Australian, 15 January 2011). This narrative continued into 2012, with the big freeze in Europe cited as further evidence that global "warming" is a farce.

\section{Confusing climate change: "set your head spinning"}

Confusion (15 articles) results from individual lack of understanding of the scientific process, as well as from media misrepresentation of this process or of the facts relating to the 2011 Brisbane flood, floods in general or climate change. Here, there is wide variation in understanding of scientific consensus on climate change, with some articles depicting a situation in which roughly equal evidence exists to support arguments for and against anthropogenic causes of climate change. Others reveal confusion from confounding or simplifying relationships between climate change and other hydrological or climatic processes.

"Many facts on both sides are still disputed and peer reviewed papers are written supporting both sides. Some saying the planet is warming and others cooling. Some stating it's man-made and others dismissing the possibility. Five minutes on Google will set your head spinning" (LTE, Cairns Post, 24 January 2011).

"As for using 100 years of recorded weather data to make conclusions about future climate change, climate scientists are the first to acknowledge they have no, or very little, confidence in historical climate statistics as predictors of future climate" (Journalist, Courier Mail, 7 February 2011).

There is a subtle but important distinction between this Confusing narrative and the Linking narrative in terms of acknowledging uncertainty surrounding the causes of flood events, and the inability to characterize single events as expressions of climate change. This narrative is also differentiated from the Denying narrative which uses uncertainty to support its claims that there is insufficient evidence for anthropogenic climate change to justify action.

\section{Proving climate change: "global warming is the cause"}

The fourth narrative ( 7 articles) makes a direct link between climate change and the 2011 Brisbane flood. In some articles, this narrative invokes the concept of scientific proof, asserting that scientists and other experts believe the flood proves the reality of climate change: "...leading scientists believe the recent floods and cyclones in Queensland are proof of climate change, and the fires in Victoria in 2009 are also consistent with expected global warming outcomes" (Journalist, Courier Mail, 4 June 2011).

This narrative generally reduces understanding of causality to single factors, identifying climate change as "the" cause of the Brisbane flood, with an uncontested consequence: "We've endured the worst nationwide flood in our history \& u idiots can't wait 2 bag, blame \& spew 4th yr ignorance! Global warming is the cause \& the weather is going 2 get even more erratic! Heads out of butts people \& deal with it!" (Chatroom, Gold Coast Bulletin, 18 January 2011).

Having established the cause, articles then make a logical progression to discussing implications of climate change and adaptation, posing questions such as "What are 
the costs to adapt?" and "Who pays?" Specific proposals for solutions are given, ranging from greater collaboration between the levels of government to assist communities exposed to flood threats, to reserving half of Canberra's planned mineral resources rent tax for a repairs fund.

Lessons for and learning by governments

We investigated the discourse around "government" to examine evidence that the flood event was a catalyst for learning by governments at the SEQ regional scale (i.e. state and SEQ local governments). Here, we inductively identified relevant "government" narratives that emerged in the discourse: learning from the past; learning from the response to the flood event and clean-up; and the formal learning through the Queensland Floods Commission of Inquiry.

\section{Learning from the past: "the dam would end major flooding in Brisbane"}

A strong narrative (44 articles) was the failure of governments to learn from previous floods which was reflected in land use planning decisions taken in a rapidly urbanizing region. Discussed was the role of both state and local governments in permitting building on flood-prone land which contributed to the vulnerability of the population. The Courier Mail would "blame the generations of state and local government politicians and planners who have allowed Brisbane to develop the way it has ... the same question was being mused in the February 3, 1974...less than a week after a flood even worse than this year's" (19 January 2011). Residents complained they bore the burden of "sadness of devastation and human loss" that resulted from "decades of planning decisions that have seen parts of Brisbane once considered flood prone become prime real estate". Rapid development during a decade of drought was noted to contribute to development of flood-prone land because "you forget, because of 10 years of drought, that land floods" (local government representative, The Australian, 10 January 2011). Articles and letters quoted government reports from 1999 or 2003 that had been ignored despite showing the flooding potential of areas released for housing. Ex-officials described efforts to curb this, for example, "When I was a senior development assessor with the Brisbane City Council, I warned applicants not to build in the floodplains or to significantly raise their dwellings" (Courier Mail, 27 January 2011). Confidence in building in these areas was also attributed to the prevalent belief that Brisbane has been flood proofed by dam infrastructure: government officials from 1974 had promised the "building of the dam would end major flooding in Brisbane" (ibid). Mayor Newman acknowledged deficient "policies between 1974 and 2004 have contributed to the problems in this flood... and more should have been done in terms of flood preparedness" (The Australian, 14 January 2011).

The dual role of Wivenhoe Dam: "water and politics are a dangerous cocktail"

The role and management of Wivenhoe Dam prior to and during the flood was a key narrative (28 articles). Discussed was the tension between dual role of the dam in both water provision and flood mitigation. As Wayne Smith reports in The Australian (13 January 2011): "In opening the dam in October 1985, then premier Joh Bjelke-Petersen boasted that it would act as a buffer against future disasters, but that was a promise based on the premise that its primary function was as a flood barrier not as a water storage facility". However, the prolonged drought prior to the flood made water a political issue in which "every drop of water...is precious" which led to the change in the role of the dam "from a flood-mitigation dam to a combined water-supply and flood-mitigation dam" (LTE, The Australian 20 January 2011). Retired engineer Ian Chalmer summed up the tension: "you would have to have very large balls to significantly reduce the dam's volumes... after 10 years of drought, because if you had got it wrong you would be accused of wasting the water" (The Australian, 15 January 2011). Several LTE noted the water supply had become politicized as "The use of Wivenhoe Dam for water storage instead of flood mitigation-and the creation of a culture centred on conserving water-is a political decision, not a public service decision" (The Australian, 19 March 2012). And "perhaps a future inquiry could query the wisdom of giving SEQ Water such conflicting objectives...The inquiry might also review the government practice of devolving critical (often unpopular) decisions to quasi-government bodies. Complex critical decisions involving public safety should remain under direct political control with ministerial accountability" (The Australian, 18 January 2011). By January 2012, the discourse (29 articles) focused on the flood inquiry proceedings and the adequacy and implementation of the Wivenhoe Dam manual in the evidence, expertise and decision-making processes concerning the water release from the dam.

Thoughtful recovery: "be smart about how, where you repair"

Broad lessons for the region's recovery and reconstruction were advocated by residents ( 20 articles) which suggested that lessons for the future were being considered. For 
example, it was recognized by many that rebuilding needed to be done quickly but strategically. "Planners and government officials must deal with the nuanced task of balancing the need of getting recovery dollars quickly into the hands of local residents and institutions with creating a comprehensive plan for mitigating against future disasters" (US disaster expert, The Australian, 21 January 2011). This vulnerability of key infrastructure was recognized-“you can be smart about how you repair and where you repair roads and bridges and railways" — and in some cases linked to potentially increased risks of these events in a changing climate. Transport infrastructure was identified as critical to ensure communities are not left isolated or without supplies and also for industry: some "bridges may have to be moved ... to flood-proof them for the future", and some "roads out west ... critical to the movement of cattle to get them to market". One common view was that such upgrade works would prove impractical given the already huge costs. In particular, the city's food distribution hub and emergency services infrastructure were identified as needing to be relocated with: "hospitals, police, fire and ambulance stations very close to the coast". An important lesson was noted for new infrastructure as the installation of the national broadband network is currently "removing a layer of redundancy that could be vital in an emergency by insisting Telstra tear up its existing network" (Journalist, Weekend Australian, 22 January 2012). There was also discussion that "politicians face stark choices on infrastructure spending and priorities" and the challenge to not "panic and develop knee-jerk responses" and with a call for "bureaucratic process... to be tempered with common sense, creativity and compassion".

\section{The flood inquiry: the "day of reckoning" where "the lessons that can be learnt will be learnt"}

Formal learning processes were instituted immediately after the 2011 flood event through the flood inquiry (16 articles in 2011) for which Premier Bligh's stated intent was to "help honour those who had lost their lives, by learning the lessons of the event" (Sydney Morning Herald, 17 January 2011) and which would "inform our response in the future". Through LTE the public urged the inquiry to ensure the "day of reckoning" "would not be too political" and any "examination should be constructive rather that destructive". Much of the discourse (23 articles) around the inquiry and management of Wivenhoe Dam ultimately rested on the dam's manual and how this translated into operational strategies during the flood. However, the role of the government leadership was also a strong narrative: "The grilling of dam engineers is not the pivotal issue for the flood inquiry. Much more important is the leadership or lack thereof from the Government" (LTE, Courier Mail, 4 February 2012).

However, the potential for constructive examination from the inquiry was influenced by credibility of the inquiry and the timing of the inquiry's final report which coincided with election campaigns for both state and local government. This resulted in the flood inquiry (27 articles in 2012) becoming politicized. The 654-page inquiry report included 175 recommendations, but also warned: "Complacency about flood prevailed, at least in parts of the state, over many years. And there is a risk that the recommendations made here will be taken up in the short term, but, absent another flood disaster in the next few years, priorities will drift and the lessons will be forgotten" (Floods Commissioner, Courier Mail, 26 March 2012). For some the report was considered costly and provided little resolution. "Many flood victims are still traumatised by their experiences, and this inquiry will do little to put their minds at rest" (Journalist, Courier Mail, 17 March 2012): and derided as a "witch hunt" delivering "mind-boggling stuff" when "after a year of evidence and deliberation, the Floods Commission of Inquiry has said it is ill-advised to release untold amounts of water during heavy flooding" (Talking Point, Courier Mail, 19 March 2013).

\section{Supporting the Mud Army: "the people of this city rising} up"

There were important lessons for government in the media discourse (10 articles) around the mobilization of the region's social capital-best presented through many media images of the Mud Army (Leitch and Bohensky 2011). Around 200,000 people, many reportedly recruited following media images or self-recruited via social media (McDonald et al. 2012), were "a veritable army of friends, colleagues and total strangers eager, as so many say, to just do what they could" in cleaning up private and business premises. The government ensured this "legend" of community self-organization will endure through a statue commissioned by Premier Bligh who said "There are few images that will be as enduring...as the people of this city rising up in the days after the flood and forming that remarkable Mud Army" (January 2012). Local government was praised as "the council coordination effort made volunteering far easier for more people than it otherwise would have been". Also expressed was "relief" in the absence of "workplace health and safety zealotry" as "people are at last able to temporarily take responsibility for their own actions without bureaucratic interference or mandatory training courses on shovel handling, et cetera" (Talking Point, The Australian, 17 January 2011). 


\section{Discussion}

Resilience theory emphasizes the ability to learn and adapt, including in disasters (Brown and Westaway 2011). In practice, disaster management is often segmented into four discrete phases: prevention, preparedness, response and recovery. This approach guides numerous Australian disaster agency operations, some criticism notwithstanding (Crondstedt 2008). A resilience approach would treat these phases holistically, with recovery feeding directly into prevention in subsequent cycles, as envisaged in some disaster planning documents (EMQ 2011), and with learning occurring throughout. In reality, these phases involve responsibilities within the remit of different agencies (Serrao-Neumann et al. 2013) working at different organizational levels and with high social complexity (Keys et al. 2013). The question that follows is: How can the benefits of resilience theory be built into and harnessed in a multi-scale, multi-agency environment?

Natural disasters can be "focusing events" (Kreibich et al. 2011) and "windows of opportunity" (Ashlin and Ladle 2007) to effect learning among society at large. Constructions of resilience were a key part of the community response to the flood and may influence whether the media discourse has a positive or negative effect on community resilience, as we discuss below.

\section{Aspects of the media discourse that supported resilience}

Ideas of community spirit, cohesion and coping-all considered to contribute to resilience in theory-were reiterated in the media discourse. This was likely to reinforce the notion among both the affected and wider community that the city was able to self-organize through agency, communication and cooperation, rather than promote the usual media focus on stories of helplessness (Ride and Bretherton 2011). The iconic images of the success of the Mud Army, through efficiency of clean-up and establishment of new networks, showed the amount of social capital that existed across the region and still functioned one year later. Additional aspects of the media discourse also have potential to expand understanding of the flood in a system resilience context, for example, the emphasis on trade-offs that may arise in regions being managed for multiple objectives, facing an array of pressures (Roiko et al. 2012) and striving to build resilience across spatial and temporal scales (Carpenter et al. 2012).

More than half the articles we analyzed articulate, through the Linking and Proving narratives, awareness of the potential for intensified extreme weather events in the future due to climate change. These narratives highlighted that while extreme weather events are an inherent part of the Australian landscape, climate and other drivers are exceeding the range of variability previously experienced by individuals and institutions (Steffen et al. 2007; Rockström et al. 2009). These narratives contribute to learning by noting the importance of considering evidence, recognizing patterns and in triggering preparedness activity by individuals or their elected representatives.

Learning in these articles was often expressed in relation to experience, with individuals or communities that had experienced disasters typically considered more resilient. Hearing others' experience or examples, sharing stories and fostering networks were emphasized as ways to learn and adapt, consistent with disaster literature that discusses the role of previous flood experience in the community learning process (Whittle et al. 2010; Koerth et al. 2013). On the other hand, the 2011 flood experience also demonstrated that past floods provide only a partial model for learning (Colten and Sumpter 2009), stressing the need for preparedness for unprecedented change, also reflected in our analysis.

Aspects of the media discourse that undermined resilience

Our analysis of the event and anniversary indicates that formal, and even informal, mechanisms to capture community learning from past extreme events are largely lacking or flawed, even one year after the event when some emergent learning might be expected. Greater attention was paid to "short-term" constructions of resilience that match political timescales (Carpenter et al. 2012), whereby concepts of community spirit, cohesion and coping overshadow and even foreclose on longer-term processes of learning. The trend observed in SEQ is consistent with reports from flood events elsewhere (Colten and Sumpter 2009; Kreibich et al. 2011). Community "spirit" in the absence of critical reflection and broad empathy can compromise the ability to learn, highlighting a divergence from some theoretical interpretations of resilience. Reflecting on the one-year anniversary of the flood, one letter chastised a "childish identification of our community response as being the Queensland spirit" (LTE, Courier Mail, 10 January 2012), arguing that other regions demonstrated similar qualities in response to more devastating events.

Floods in developed countries are tending to be portrayed not as natural disasters but as political disasters as communities begin to consider them as "foreseeable risks" (Escobar and Demeritt 2012) and government has either failed to warn of the risk or manage the cause. This obstructs the opportunity for learning as communities absolve themselves from responsibility for disaster management. All the signs suggest that the SEQ regional community was not encouraged to learn about living with floods: the widely held view that SEQ was flood proofed by 
the dam that bred individual and institutional complacency, the building on floodable land and the amount of vulnerable public and private river infrastructure. This was compounded by an increasing population (Roiko et al. 2012) which brought with it an influx of new residents with little local knowledge or experience of floods (Keogh 2011).

Even where previous flood experience exists, it may not result in learning. When there is not much information available, memories of previous events have diminished or other actors, such as government are perceived to be taking responsibility, learning is reduced as the community tends to be less prepared (Bradford et al. 2012). This is exacerbated if there are structural defences (Colten and Sumpter 2009) such as Wivenhoe Dam in SEQ. It is tenuous as to whether a flood event becomes a prompt for institutional learning, through relocation of vulnerable communities, new institutions for flood responsibilities (Whittle et al. 2010) or new insurance rules or agreements (Escobar and Demeritt 2012). Governments can play a role in fostering learning in the community, but the limited learning observed to date may highlight a need for other mechanisms and actors to lead learning processes (Keys et al. 2013). While the media narratives that we identified revealed awareness of climate change, the prominence of the Denying narrative belies the deep divisions in public understanding and the politicized nature of the issue in Australia (Leviston et al. 2011; Latham 2012). The reasons that Brisbane flooded in January 2011 sit in a complex web of factors that cannot be easily summarized as a single cause, as the media is often want to do. Instead, the complexity of climate change implies multiple responsibilities among sectors (Keys et al. 2013) and actors from local to distant. It also implies that the responsible parties must resist distilling the complex web into simplistic, inaccurate sound bites which confound the media discourse on climate change science.

On balance, we found that where evidence for learning exists, it is generally in a limited and narrow context. An article titled "Flood inquiry's real priority" is indicative: "If future similar crises are to be avoided, the commission must re-emphasize the importance of the operating manual, ensure it is updated and improved if necessary and set out transparent processes to be followed and monitored. This is judge Cate Holmes's most significant challenge" (Journalist, The Australian, 9 February 2012). That said, the true test of what learning has occurred may be yet to come.

\section{Conclusion}

In recent times SEQ has experienced extreme weather events such as drought and floods which have implications for the region's inherent resilience. Clear lessons from the 2011 Brisbane flood may be yet to emerge, but there is evidence from our analysis of news media that some, albeit limited, learning is taking place in terms of consideration of climate change and the difficulties in adjustments and trade-offs required for adaptation. How this learning continues or expands depends largely on government responses through policies that support more enduring lessons and adaptation as extreme events move from a local to a global climate context. Timing and context in framing events are also important to catalyze learning to trigger adjustments as priorities change: as managing for drought overtakes lessons from previous floods, and as findings from formal inquiries get overrun by election campaigns and cycles.

This analysis aids understanding of how, through the lens of news media, a lack of learning among public actors and agencies in the 2011 Brisbane flood may be serving to inhibit SEQ's resilience. It also suggests that if "resilience" is to become a useful guiding principle in these realms, it may require a more nuanced appreciation in the public discourse.

A Townsville Bulletin journalist's summary as the flood waters subsided on 15 January 2011 offers a fitting conclusion:

"It's impossible not to be touched by the stories that are coming out of the Queensland floods: grief, heroism, sacrifice, optimism, hope, resilience - the capacity of the human race to overcome adversity is staggering. On the other hand we don't learn much. How could they possibly imagine it would never happen again? Even 1974 wasn't the first one .... The remarkable thing is that we got away with it for 37 years. During which time the population has more than doubled. That explains why this time it's not 13,000 buildings affected, but more than 20,000 . What did we expect?"

Acknowledgments The South East Queensland Climate Adaptation Research Initiative (SEQCARI) provided funding for this analysis. Constructive comments were contributed by participants in the Initiative for Climate Adaptation Research and Understanding through the Social Sciences (ICARUS) meeting in New York in May 2012 and from Ryan McAllister and Jennifer Price at CSIRO. We thank Leah White for assistance with data collection. We also thank two anonymous reviewers for comments which substantially improved the paper.

Open Access This article is distributed under the terms of the Creative Commons Attribution License which permits any use, distribution, and reproduction in any medium, provided the original author(s) and the source are credited.

\section{References}

Adger WN (2000) Social and ecological resilience: are they related? Prog Hum Geogr 24(3):347-364

Adger WN, Hughes TP, Folke C, Carpenter SR, Rockström J (2005) Social-ecological resilience to coastal disasters. Science 308:1036-1039 
Anderies JM, Walker BH, Kinzig AP (2006) Fifteen weddings and a funeral: case studies and resilience-based management. Ecol Soc 11(1):21. (online). www.ecologyandsociety.org/vol11/iss1/art21/

Ashlin A, Ladle R (2007) 'Natural disasters' and newspapers: posttsunami environmental discourse. Environ Hazards 7:330-341

Bohensky EL, Leitch AM (2012) Framing climate change: newspaper representations of the Brisbane 2011 flood. In: Initiative on climate adaptation research and understanding through the social sciences (ICARUS) 3rd annual conference, New York, USA

Boykoff M (2011) Who speaks for the climate? Making sense of media reporting on climate change. Cambridge University Press, Cambridge

Bradford RA, O'Sullivan JJ, van der Craats M, Krywkow J, Rotko P, Aaltonen J, Bonaiuto M, De Dominicis S, Waylen K, Schelfaut K (2012) Risk perception: issues for flood management in Europe. Nat Hazard Earth Syst 12:2299-2309

Brown K (2011) Rethinking progress in a warming world: interrogating climate resilient development. In: EADI/DSA Conference, York, UK

Brown K, Westaway E (2011) Agency, capacity, and resilience to environmental change: lessons from human development, wellbeing, and disasters. Annu Rev Environ Resour 36(14):1-22

Bureau of Meteorology (BOM) (2011). Known floods in the Brisbane \& Bremer River Basin, including the cities of Brisbane and Ipswich. Bureau of Meteorology: Melbourne, Australia, 2011. http://www.bom.gov.au/hydro/flood/qld/fld_history/brisbane_ history.shtml. Accessed 12 Apr 2012

Carpenter SR, Arrow KJ, Barrett S et al (2012) General resilience to extreme events. Sustainability 4:3248-3259

Carvalho A (2008) Media(ted) discourse and society. Journal Stud 9(2):161-177

Carvalho A, Burgess J (2005) Cultural circuits of climate change in U.K. broadsheet newspapers, 1985-2003. Risk Anal 25:14571469

Colten CE, Giancarlo A (2011) Losing resilience on the Gulf Coast: hurricanes and social memory. Environ Sci Policy Sustain Dev 53(4):6-19

Colten CE, Sumpter AR (2009) Social memory and resilience in New Orleans. Nat Hazards 48:355-364

Colten CE, Hay J, Giancarlo A (2012) Community resilience and oil spills in coastal Louisiana. Ecol Soc 17(3):5. doi:10.5751/ ES-05047-170305

Commonwealth of Australia (2011) National disaster resilience strategy. Barton, Australia. www.qld.gov.au/emergency/news/ features/disasterrel.html. Accessed 26 Oct 2012

Coumou D, Rahmstorf S (2012) A decade of weather extremes. Nat Clim Change 1452:1-6

Crondstedt M (2008) Prevention, preparedness, response, recovery: an outdated concept? Aust J Emerg Manag 17:10-13

Doulton H, Brown K (2009) Ten years to prevent catastrophe? Discourses of climate change and international development in the UK press. Glob Environ Change 19:191-202

Emergency Management Queensland (EMQ) (2011) Queensland disaster management arrangements participant guide version 2.2. Department of Community Safety, Brisbane, Australia

Escobar MP, Demeritt D (2012) Flooding and the framing of risk in British broadsheets, 1985-2010. Public Underst Sci. doi:10.1177/ 0963662512457613

Folke C, Hahn T, Olsson P, Norbert J (2005) Adaptive governance of social ecological systems. Annu Rev Environ Resour 30:441-473

Godschalk DR (2003) Urban hazard mitigation: creating resilient cities. Nat Hazards Rev 4:136-143

Gortner EM, Pennebaker JW (2003) The archival anatomy of a disaster: media coverage and community-wide health effects of the Texas A\&M bonfire tragedy. J Soc Clin Psychol 22:580-603
Hansen J, Sato M, Kharecha P, Beerling D, Masson-Delmotte V, Pagani M, Raymo M, Royer DL, Zachos JC (2008) Target atmospheric $\mathrm{CO}_{2}$ : where should humanity aim? Open Atmos Sci J 2:217-231

Hayes J, Goonetilleke A (2012) Building community resiliencelearning from the 2011 floods in Southeast Queensland, Australia. In: Kakimoto RY, Fumihiko (eds) 8th Annual conference of international institute for infrastructure, renewal and reconstruction, Kumamoto, Japan, pp 51-60

Holliman R (2004) Media coverage of cloning: a study of media content, production and reception. Public Underst Sci 13: $107-130$

IPCC (2007) Climate Change 2007: Synthesis Report. Contribution of Working Groups I, II and III to the Fourth Assessment Report of the Intergovernmental Panel on Climate Change, RK Pachauri, A Reisinger, Eds., IPCC, Geneva, Switzerland

Keogh DU (2011) Resilience, vulnerability and adaptive capacity of an inland rural town prone to flooding: a climate change adaptation case study of Charleville, Queensland, Australia. Nat Hazards 59:699-723

Keys N, Bussey M, Thomsen DC, Lynam T, Smith TF (2013) Building adaptive capacity in South East Queensland, Australia. Reg Environ Change. doi:10.1007/s10113-012-0394-2

Koerth J, Vafeidis AT, Hinkel J, Sterr H (2013) What motivates coastal households to adapt pro-actively to sea-level rise and increasing flood risk? Reg Environ Change. doi:10.1007/s10113012-0399-x

Kreibich H, Seifert I, Thieken A, Lindquist E, Wagner K, Merz B (2011) Recent changes in flood preparedness of private households and businesses in Germany. Reg Environ Change 11:59-71

Latham M (2012) Climate change denial not just for fools. Australian Financial Review, 20 April 2012. http://afr.com/p/lifestyle/ review/climate_change_denial_not_just_for_sFAw16a7QU34 KIj2tmN4eJ. Accessed 23 Apr 2012

Leitch AM, Bohensky EL (2011) Picturing resilience analysis of newspaper images of 2011 Brisbane floods. In: Visualizing science and environment. University of Brighton, UK

Leviston Z, Leitch A, Greenhill M, Leonard R, Walker I (2011) Australians' views of climate change. CSIRO, Canberra

Liu X, Vedlitz A, Alston L (2008) Regional news portrayals of global warming and climate change. Environ Sci Policy 11:379-393

Manyena SB (2006) The concept of resilience revisited. Disasters $30: 434-435$

McComas K, Shanahan J (1999) Telling stories about global climate change: measuring the impact of narratives on issue cycles. Commun Res 26(1):30-57

McDonald L, Sonn L, Sun H, Creber M (2012) Developing public disaster communication for volunteer recruitment: understanding volunteer motivations. World Public Relations, 18 Nov 2012, Melbourne, VIC

Miles B, Morse S (2007) The role of news media in natural disaster risk and recovery. Ecol Econ 63:365-373

Min S, Zhang X, Zwiers FW, Hegerl GC (2011) Human contribution to more-intense precipitation extremes. Nature 470: 378-381

Nicholls RJ (2011) Planning for the impacts of sea level rise. Oceanography 24:144-157

Nisbet MC, Feldman L (2011) The social psychology of political communication. In: Hook D, Franks B, Bauer M (eds) The social psychology of communication. Palgrave Macmillan, London, pp 284-299

Norris F, Stevens S, Pfefferbaum B, Wyche K, Pfefferbaum R (2008) Community resilience as a metaphor, theory, set of capacities, and strategy for disaster readiness. Am J Community Psychol $41: 127-150$ 
Pelling M (2003) The vulnerability of cities: social resilience and natural disaster. Earthscan, London

Pittock J (2011) Dammed if you do. GWF Discussion Paper 1102, Global Water Forum, Canberra, Australia. Available online at: http://www.globalwaterforum.org/2011/10/01/damned-if-you-do/. Accessed 13 Nov 2012

Queensland Floods Commission of Inquiry (QFCI) (2011) Interim report. Brisbane, Australia

Queensland Floods Commission of Inquiry (QFCI) (2012) Final report. Brisbane, Australia

Ride A, Bretherton D (2011) Community resilience in natural disasters. Palgrave Macmillan, London

Rockström J, Steffen W, Noone K, Persson A, Chapin FS III, Lambin E, Lenton TM, Scheffer M, Folke C, Schellnhuber H, Nykvist B, De Wit CA, Hughes T, van der Leeuw S, Rodhe H, Sörlin S, Snyder PK, Costanza R, Svedin U, Falkenmark M, Karlberg L, Corell RW, Fabry VJ, Hansen J, Walker B, Liverman D, Richardson K, Crutzen P, Foley J (2009) Planetary boundaries: exploring the safe operating space for humanity. Ecol Soc 14(2):32. http://www.ecologyandsociety.org/vol14/iss2/art32/

Roiko A, Mangoyana R, McFallan S, Carter RW, Oliver J, Smith TF (2012) Socio-economic trends and climate change adaptation: the case of South East Queensland. Australas J Environ 19(1):35-50

Serrao-Neumann S, Crick F, Harman B, Sano M, Sahin O, van Staden R, Schuch G, Baum S, Low Choy D (2013) Improving crosssectoral climate change adaptation for coastal settlements: insights from South East Queensland, Australia. Reg Environ Chang. doi:10.1007/s10113-013-0442-6

Smit B, Wandel J (2006) Adaptation, adaptive capacity and vulnerability. Glob Environ Change 16:282-292
Sonnett J (2010) Climates of risk: a field analysis of global climate change in US media discourse, 1997-2004. Pub Underst Sci 19(6):698-716

Spence A, Poortinga W, Butler C, Pidgeon NF (2011) Perceptions of climate change and willingness to save energy related to flood experience. Nat Clim Change 1059:46-49

Steffen W, Crutzen PJ, McNeill JR (2007) The Anthropocene: are humans now overwhelming the great forces of nature. Ambio 36:614-621

Turner BLII, Kasperson RE, Matson PA, McCarty JJ, Corell RW, Christensen L et al (2003) A framework for vulnerability analysis in sustainability science. Proc Natl Acad Sci USA 100(14):8074-8079

van den Honert RC, McAneney J (2011) The 2011 Brisbane floods: causes, impacts and implications. Water 3:1149-1173

Walker B, Westley F (2011) Perspectives on resilience to disasters across sectors and cultures. Ecol Soc 16(2):4. http://www.ecolo gyandsociety.org/vol16/iss2/art4/

Walker B, Carpenter S, Anderies J, Abel N, Cumming G, Janssen M, Lebel L, Norberg J, Peterson GD, Pritchard R (2002) Resilience management in social-ecological systems: a working hypothesis for a participatory approach. Conserv Ecol 6(1):14. http://www. consecol.org/vol6/iss $1 /$ art 14

Whitmarsh L (2008) Are flood victims more concerned about climate change than other people? The role of direct experience in risk perception and behavioural response. J Risk Res 11:351-374

Whittle R, Medd W, Deeming H, Kashefi E, Mort M, Twigger RC, Walker G, Watson N (2010) After the rain-learning the lessons from flood recovery in Hull, final project report for "flood, vulnerability and urban resilience: a real-time study of local recovery following the floods of June 2007 in Hull". Lancaster University, Lancaster 